\title{
KONTRIBUSI SEKTOR PERTANIAN TERHADAP PDRB KABUPATEN JEMBER TAHUN 2012-2016
}

\author{
Febri Haris Putra ${ }^{1}$, Hety Mustika Ani ${ }^{1}$, Wiwin Hartanto ${ }^{1}$ \\ ${ }^{1}$ Program Studi Pendidikan Ekonomi, Fakultas Keguruan dan Ilmu Pendidikan, Universitas Jember \\ e-mail: Hety.fkip@unej.ac.id
}

\begin{abstract}
Abstrak
Sektor pertanian Kabupaten Jember yang merupakan salah satu sektor yang menyumbang pendapatan daerah terbesar. Pendapatan daerah dapat diketahui dari Tujuan penelitian ini untuk mengetahui ramalan trend PDRB Kabupaten Jember, dan besarnya kontribusi sektor tersebut terhadap PDRB Kabupaten Jember. Jenis penelitian ini adalah analisis deskriptif kuantitatif. Data yang digunakan adalah data Sekunder. Metode pengumpulan data menggunakan studi dokumen yang bersumber dari BPS Kabupaten Jember. Analisis data menggunakan (1) Analisis trend untuk mengetahui ramalan trend PDRB untuk 5 tahun kedepan, dan (2) analisis proporsionalitas untuk mengetahui kontribusinya terhadap PDRB Kabupaten Jember. Hasil penelitian menunjukkan bahwa (1) Ramalan pada tahun 2017 sebesar 29,85\% lebih rendah dari tahun 2016 yaitu 30,2 \%, kemudian tahun 2018 sebesar 29,5\%. (2) Total kontribusi sektor pertanian terhadap PDRB Kabupaten Jember adalah sebesar 1,07 \% selama kurun waktu 2012-2016.
\end{abstract}

Kata Kunci: Kontribusi, Sektor Pertanian, Kabupaten Jember.

\section{PENDAHULUAN}

Kabupaten Jember merupakan salah satu kabupaten yang memiliki sektor pertanian yang berkembang baik di wilayah eks karesidenan besuki. Subsektor pertanian di Kabupaten Jember memberikan kontribusi PDRB Terbesar selama kurun waktu 2012-2106. Kabupaten Indramayu sangat potensial untuk dikembangkan sebagai sentra produksi pertanian khususnya komoditas perkebunan, karena komoditas ini merupakan komoditas dengan kontribusi PDRB terbesar di Kabupaten Jember selama beberapa tahun terakhir (BPS Jember, 2018)

Sektor pertanian yang berkembang di wilayah ini terdapat beberapa jenis komoditas diantaranya komoditas tanaman pangan, holtikultura, perkebunan, perikanan, peternakan dan jasa pertanian. Keenam komoditas ini menjadi sumber peningkatan PDRB sektor pertanian dikarenakan wilayah Kabupaten Jember yang memiliki letak geografis yang memadai sehingga dapat dikembangkan sektor-sektor ini secara sempurna.

Produk Domestik Regional Bruto (PDRB) yang ada di Kabupaten Jember terdapat 9 sektor jenis usaha yang menjadi penyumbang dan penggerak roda perekonomian di wilayah ini. 9 sektor usaha ini yaitu (1) Pertanian, (2) Pertambangan dan penggalian, (3) Industri Pengolahan, (4) Listrik, gas dan air bersih, (5) Bangunan, (6) Perdagangan, hotel dan restoran, (7) Pengangkutan dan komunikasi, (8) Keuangan, persewaan dan jasa perusahaan, dan (9) Sektor jasa lainnya. Berdasarkan pemaparan diatas, penelitian ini bertujuan mengetahui besarnya kontribusi sektor pertanian terhadap PDRB Kabupaten Jember Tahun 2012-2016.

\section{METODE}

Penelitian ini merupakan penelitian analisis deskriptif kuantitatif yang dilakukan di Kabupaten Jember dengan menganalisis rekapitulasi data PDRB Kabupaten Jember yang bersumber dari Badan Pusat Statistik (BPS) Kabupaten Jember. Metode pengumpulan data yang digunakan adalah studi dokumen yang bersumber dari BPS Kabupaten Jember. Penelitian ini menggunakan analisis trend, dan analisis proporsionalitas guna menemukan besarnya kontribusi sektor pertanian terhadap PDRB Kabupaten Jember tahun 2012-2016 yang diperoleh peneliti dari Badan Pusat Statistik (BPS) Kabupaten Jember.

\section{HASIL DAN PEMBAHASAN \\ Hasil Penelitian}

Penelitian ini menggunakan analisis trend yang digunakan untuk melihat ramalan PDRB untu 5 tahun kedepan, dan analisis proporsionalitas untuk melihat besarnya kontribusi sektor pertanian terhadap PDRB Kabupaten Jember. Analisis Trend merupakan suatu analisis untuk meramalkan suatu objek penelitian di masa yang akan datang. Analisis ini peneliti gunakan untuk meramalkan nilai trend produksi komoditas tanaman pangan sektor pertanian di Kabupaten Jember. Dengan mengacu pada beberapa data unit analisis yaitu data PDRB Kabupaten Jember khusus sektor pertanian, kemudian unit analisis data produksi komoditas tanaman pangan perkecamatan di Kabupaten Jember, Kemudian data PDRB Komoditas pertanian secara umum mulai dari tahun 2012 hingga tahun 2016. 
Analisis yang peneliti ramalkan adalah untuk 5 tahun kedepan sesuai dengan rumus analisis trend dengan metode kuadrat kecil (Least Square Method) yaitu analisis menggunakan kuadrat minimum karena tahun analisis yang hanya 5 tahun. Analisis ini menggunakan data PDRB pertanian pada tahun 2012 hingga 2016 dengan menggunakan time series yang bernilai 5 tahun sehingga $\mathrm{n}$ menjadi 5 . Hasilnya dapat kita lihat didalam tabel berikut ini.

Tabel 3 Analisis Trend PDRB Sektor Pertanian Kabupaten Jember

\begin{tabular}{ccccc}
\hline Tahun & Produksi ( Y ) & Series $(\mathbf{X})$ & X.Y & X (kuadrat) \\
\hline 2012 & 31.78 & -2 & -63.56 & 4 \\
2013 & 31.06 & -1 & -31.06 & 1 \\
2015 & 30.66 & 1 & 30.66 & 1 \\
2016 & 30.25 & 2 & 60.5 & 4 \\
Jumlah & $\mathbf{1 5 4 . 4 9}$ & $\mathbf{0}$ & $\mathbf{- 3 . 4 6}$ & $\mathbf{1 0}$ \\
Average (a) & $\mathbf{3 0 . 9 0}$ & & & \\
(b) & $\mathbf{- 0 . 3 5}$ & & & \\
\hline
\end{tabular}

Sumber : Data Diolah, 2018

Data diatas diperoleh dari rekapitulasi PDRB sektor pertanian Kabupaten Jember, diketahui nilai a sebesar 30,90 dan nilai b sebesar $(-0,35)$. Secara umum persamaannya adalah $Y=30.90-0,35 x$, untuk lebih jelasnya dapat diperhatikan tabel berikut :

Tabel 4 Hasil Trend PDRB Kabupaten Jember

\begin{tabular}{cccccc}
\hline Tahun & Persamaan & A & b & x & Ramalan Trend Produksi (persen) \\
\hline 2012 & $\mathrm{y}=\mathrm{a}+\mathrm{b} \mathrm{x}$ & 30.90 & -0.35 & -2 & 31.6 \\
2013 & $\mathrm{y}=\mathrm{a}+\mathrm{b} \mathrm{x}$ & 30.90 & -0.35 & -1 & 31.25 \\
2014 & $\mathrm{y}=\mathrm{a}+\mathrm{b} \mathrm{x}$ & 30.90 & -0.35 & 0 & 30.9 \\
2015 & $\mathrm{y}=\mathrm{a}+\mathrm{b} \mathrm{x}$ & 30.90 & -0.35 & 1 & 30.55 \\
2016 & $\mathrm{y}=\mathrm{a}+\mathrm{b} \mathrm{x}$ & 30.90 & -0.35 & 2 & 30.2 \\
$\mathbf{2 0 1 7}$ & $\mathbf{y}=\mathbf{a}+\mathbf{b} \mathbf{x}$ & $\mathbf{3 0 . 9 0}$ & $\mathbf{- 0 . 3 5}$ & $\mathbf{3}$ & $\mathbf{2 9 . 8 5}$ \\
$\mathbf{2 0 1 8}$ & $\mathbf{y}=\mathbf{a}+\mathbf{b} \mathbf{x}$ & $\mathbf{3 0 . 9 0}$ & $\mathbf{- 0 . 3 5}$ & $\mathbf{4}$ & $\mathbf{2 9 . 5}$ \\
$\mathbf{2 0 1 9}$ & $\mathbf{y}=\mathbf{a}+\mathbf{b} \mathbf{x}$ & $\mathbf{3 0 . 9 0}$ & $\mathbf{- 0 . 3 5}$ & $\mathbf{5}$ & $\mathbf{2 9 . 1 5}$ \\
\hline $\mathbf{2 0 2 0}$ & $\mathbf{y}=\mathbf{a}+\mathbf{b} \mathbf{x}$ & $\mathbf{3 0 . 9 0}$ & $\mathbf{- 0 . 3 5}$ & $\mathbf{6}$ & $\mathbf{2 8 . 8}$ \\
\hline $\mathbf{2 0 2 1}$ & $\mathbf{y}=\mathbf{a}+\mathbf{b} \mathbf{x}$ & $\mathbf{3 0 . 9 0}$ & $\mathbf{- 0 . 3 5}$ & $\mathbf{7}$ & $\mathbf{2 8 . 4 5}$ \\
\hline
\end{tabular}

Sumber : Data Diolah, 2018

Ramalan nilai PDRB pada tahun 2017 berdasarkan tabel diatas yaitu sebesar 29,85\% lebih rendah dari tahun sebelumnya yaitu 30,2\%, kemudian untuk ramalan pada tahun 2018 adalah sebesar 29,5\% semakin menurun untuk tahun berikutnya, hingga mencapai 28,45 untu tahun 2021. Hal ini dapat disimpulkan bahwa terjadi penurunan yang fluktuatif pada PDRB sektor pertanian untuk 5 tahun kedepan yang diramalkan bisa lebih menurun lagi bahkan minus di tahun tahun berikutnya.

Selanjutnya analisis yang terakhir yaitu analisis proporsionalitas. Analisis ini digunakan oleh peneliti untuk menjawab rumusan masalah ketiga yaitu sebesar apa kontribusi sektor pertanian terhadap PDRB Kabupaten Jember tahun 2012-2016. Analisis ini mengacu kepada data data sebelumnya yaitu data hasil analisis sektor unggulan atau komoditas unggulannya kemudian data PDRB sektor pertanian tahun 2012-2016. Selanjutnya data dimasukkan kedalam rumus analisis proporsi untuk dianalisis. Untuk lebih jelasnya data analisis proporsi peneliti sajikan dalam bentuk tabel berikut :

Kemudian selanjutnya adalah analisis proporsionalitas yaitu untuk mengetahui besarnya kontribusi sektor pertanian terhadap PDRB Kabupaten Jember selama 2012-2016. Menggunakan rumus proporsi sebagai cara perhitungannya yaitu dengan membandingkan nilai total PDRB sektor pertanian selama 5 tahun dengan total PDRB kemudian mengalikannya dengan persen. Untuk lebih jelasnya dapat dilihat tabel analisis berikut ini Tabel 8 Analisis Proporsionalitas Sektor Pertanian

\begin{tabular}{clcccc}
\hline NO & \multicolumn{1}{c}{ Sektor Pertanian } & PDRB Sektor Pertanian & Total PDRB & Persentase & Hasil \\
\hline 1 & Tanaman Pangan & 40.64 & 154.49 & $100 \%$ & 0.26 \\
2 & Tanaman Holtikultura & 13.85 & 154.49 & $100 \%$ & 0.09 \\
3 & Tanaman Perkebunan & 56.54 & 154.49 & $100 \%$ & 0.37 \\
4 & Peternakan & 26.34 & 154.49 & $100 \%$ & 0.17 \\
5 & Jasa Pertanian dan Perburuan & 1.63 & 154.49 & $100 \%$ & 0.01 \\
6 & Kehutanan & 4.84 & 154.49 & $100 \%$ & 0.03
\end{tabular}




\begin{tabular}{cccccc}
\hline NO & Sektor Pertanian & PDRB Sektor Pertanian & Total PDRB & Persentase & Hasil \\
\hline 7 & Perikanan & 21.95 & 154.49 & $100 \%$ & 0.14 \\
& Jumlah & $\mathbf{1 6 5 , 7 9}$ & $\mathbf{1 . 0 8 1 , 4 3}$ & & $\mathbf{1 , 0 7}$ \\
\hline
\end{tabular}

Sumber : Data Diolah, 2018

Total sumbangan atau kontribusi sektor tanaman perkebunan sebagai komoditas potensial di Kabupaten Jember berdasarkan tabel 8 diatas adalah sebesar 0,37\% dari PDRB Kabupaten Jember, kemudian diikuti oleh komditas tanaman pangan sebagai komoditas terbesar kedua yaitu sebesar 0,26 \% dari PDRB Kabupaten Jember, dan terakhir diikuti komoditas peternakan sebesar 0,17 \% dari total PDRB Kabupaten Jember periode 2012-2016 sebagai komoditas terbsar ketiga. Total kontribusi sektor pertanian terhadap PDRB Kabupaten Jember adalah sebesar $\mathbf{1 , 0 7} \%$ selama kurun waktu 2012 hingga tahun 2016.

\section{Pembahasan}

Pembahasan dalam penelitian ini merupakan penjelasan hasil penelitian kontribusi sektor pertanian terhadap PDRB Kabupaten Jember Tahun 2012-2016. Kontribusi sektor pertanian dilihat dari seberapa besar sumbangan produk unggulan komoditas pertanian terhadap PDRB Kabupaten Jember dalam rangka meningkatkan pertumbuhan wilayah Kabupaten Jember khususnya dibidang pertanian sebagai sektor dominan di wilayah ini. Kontribusi ini dilihat dari ramalan produksi atau trend produksi sektor pertanian selama kurun waktu yang ditentukan peneliti guna melihat ramalan hasil yang akan terjadi ditahun selanjutnya, kemudian menemukan komoditas unggulan sektor pertanian di Kabupaten Jember guna melihat besarnya kontribusi dari komoditas unggulan ini terhadap Produk Domestik Regional Bruto (PDRB) Kabupaten Jember.

Hasil analisis trend PDRB menunjukkan bahwa sektor pertanian dimasa mendatang akan mengalami penuruanan yang fluktuatif, yaitu pada tahun 2017 hingga 2021 dapat dilihat semakin mengurun. Hal ini disebabkan karena beberapa hal seperti yang telah dijelaskan oleh Bupati Kabupaten Jember dalam sidang Laporan Keterangan Pertanggungjawaban (LKPJ) tahun anggaran 2015 lalu (BPS Kabupaten Jember, 2018) yaitu karena "adanya kombinasi naik turunnya produksi dari subsektor tanaman pangan, peternakan, perkebunan, perikanan dan kehutanan"

Hal ini sama persis dengan penelitian yang dilakukan oleh Ika Dwi Nurjayanti (2012) di Kabupaten Pati, Jawa Tengah, bahwasannya penurunan produksi sektor pertanian dikarenakan oleh beberapa aspek seperti iklim, bencana alam dan hama penyakit yang juga menyebabkan daerah Kabupaten Pati hampir mengalami gagal panen di Sektor Perkebunannya. Naik dan turunnya jumlah produksi sektor pertanian ini menyebabkan terjadinya fluktuasi jumlah sumbangan sektor pertanian terhadap PDRB suatu wilayah.

Hal tersebut sesuai dengan pendapat Maryati (2010:129) bahwa gerakan naik turun dalam jangka waktu yang panjang diperoleh dari rata-rata perubahan waktu akan menghasilkan trend positif jika hasil rata-rata perubahan yang cenderung bertambah atau meningkat dan trend negatif jika sebaliknya. Jadi trend yang terjadi untuk produksi tanaman pangan pada tahun 2017 merupakan trend positif dan pada tahun 2018 merupakan trend negatif. Kemudian untuk trend PDRB dari tahun ke tahun cenderung menurun atau dapat dikatakan sebagai trend negatif.

Situasi ini menimbulkan adanya penurunan sumbangan sektor pertanian terhadap PDRB Kabupaten Jember yang mana sektor pertanian merupakan sektor yang dominan dan sudah berkembang dikalangan masyarakat jember yang merupakan salah satu sumber penghasilan utama, namun dengan adanya penurunan tersebut "Bupati jember menyatakan telah menyiapkan strategi khusus yaitu dengan melakukan insentifikasi dan pengolahan produk pertanian yang diharapkan kedepannya dapat menjadi daya ungkit perekonomian di sektor pertanian".

Sektor pertanian menyumbang terbesar terhadap PDRB meskipun setelah dita ramal kedepannya akan terjadi penurunan, namun besarnya kontribusi sektor pertanian ini masih tetap stabil dibandingkan dengan sektor lainnya di Kabupaten Jember. Kontribusi sektor pertanian ini menjadi faktor pendukung perekonomian di Kabupaten Jember agar dapat meningkatkan sumbangannya terhadap Produk Domestik Regional Bruto (PDRB) di wilayah Jember. Total sumbangan atau kontribusi sektor tanaman perkebunan sebagai komoditas potensial di Kabupaten Jember berdasarkan tabel 8 diatas adalah sebesar 0,37\% dari PDRB Kabupaten Jember, kemudian diikuti oleh komditas tanaman pangan sebagai komoditas terbesar kedua yaitu sebesar 0,26 \% dari PDRB Kabupaten Jember, dan terakhir diikuti komoditas peternakan sebesar 0,17 \% dari total PDRB Kabupaten Jember periode 2012-2016 sebagai komoditas terbsar ketiga. Total kontribusi sektor pertanian terhadap PDRB Kabupaten Jember adalah sebesar 1,07 \% selama kurun waktu 2012 hingga tahun 2016.

Berdasarkan pembahasan diatas diketahui besarnya sumbangan atau kontribusi sektor pertanian Kabupaten Jember pada tahun 2012-2016 yang berasal dari komoditas sektor pertanian yang berkembang sebagai sektor potensial di wilayah Kabupaten Jember sebagai sektor dominan dan menguntungkan bagi masyarakat Jember khususnya. 


\section{PENUTUP}

Berdasarkan pembahasan diatas dapat disimpulkan bahwa kontribusi sektor pertanian terhadap PDRB kabupaten Jember sangat besar sehingga perlu adanya tinjauan lebih lanjut oleh pemerintah guna meningkatkan kontribusi sektor pertanian. Hasil analisis Trend produksi sektor pertanian di Kabupaten Jember selama kurun waktu 5 tahun megalami penurunan. Ramalan pada tahun 2017 dan 2018 bergeser lebih rendah dari pada tahun sebelumnya, pada tahun 2017 sebesar 29,85\% lebih rendah dari tahun 2016 yaitu 30,2\% dan pada tahun 2018 sebesar 29,5\% kemudian pada tahun 2019 hingga 2021 semakin menurun hingga mencapai 28,45 ditahun 2021 nanti jika tidak ada tindakan dari pemerintah terkait perbaikan dan evaluasi sektor pertaniannya.

Hasil Analisis Proporsionalitas diketahui total kontribusi sektor pertanian terhadap PDRB Kabupaten Jember adalah sebesar 1,07\% selama kurun waktu 2012 hingga tahun 2016. Kenyataan ini perlu adanya kebijakan dan tindakan oleh pemerintah terkait masalah yang terjadi di Kabupaten Jember, sehingga nantinya dapat menunjang sektor pertanian sebagai sektor dominan di wilayah ini untuk menyumbang dan meningkatkan Produk Domestik Regional Bruto (PDRB) Kabupaten Jember demi kesejahteraan dan Kemakmuran masyarakat Jember khususnya.

\section{DAFTAR PUSTAKA}

Badan Pusat Statistik. 2018. Kabupaten Jember Dalam Angka. https://jemberkab.bps.go.id/. [diakses 02 mei 2018].

BPS Kabupaten Jember 2012-2016. Rencana Pembangunan Kabupaten Jember. [diakses 02 Mei 2018].

Darmawan, D. 2012. Analisis Penentuan Sektor Unggulan Kabupaten Jember. http://repository.unej.ac.id/bitstream/handle/123456789/27194/gdlhub\%20\%20(52) 1.pdf? sequence=1. [diakses 02 Mei 2018].

Jhingan, M L .2013. Ekonomi Pembangunan dan Perencanaan. Jakarta : PT. Rajagrafindo Persada.
Maryati,
2010.
Strategi
Pembelajaran
Inkuiri.
http://staff.uny.ac.id/sites/default/files/pendidikan//maryatissimsi/7strategipembelajaran-inkuiripdf.pdf. [diakses tanggal 02 Mei 2018]. 